\title{
Association of the interleukin-12 polymorphic variants with the development of antibodies to surface antigen of hepatitis $B$ virus in hemodialysis patients in response to vaccination or infection
}

\author{
Alicja E. Grzegorzewska • Piotr M. Wobszal • \\ Anna Sowińska • Adrianna Mostowska • \\ Paweł P. Jagodziński
}

Received: 2 December 2012/ Accepted: 16 October 2013/Published online: 25 October 2013

(C) The Author(s) 2013. This article is published with open access at Springerlink.com

\begin{abstract}
Cytokines, involved in the T-helper 1 system, play a role in the regulation of hepatitis B virus (HBV) clearance and the immune response to $\mathrm{HBV}$ antigens during natural infection or planned vaccination. Our aim was to examine whether the polymorphic variants of $I L-12$ are equally associated with development of antibodies to HBV surface antigen (anti-HBs) in hemodialysis (HD) patients in the case of $\mathrm{HBV}$ vaccination or HBV infection. The $I L-12 A$ rs568408 and $I L-12 B$ rs3212227 polymorphisms were analyzed in relation to anti-HBs development in $602 \mathrm{HD}$ patients with negative antibodies to HBV core antigen (anti$\mathrm{HBc}$ ) who were hepatitis B vaccinated (group I) as well as in 237 anti-HBc positive HD patients who were infected
\end{abstract}

The paper was presented at the 49th ERA-EDTA Congress, Paris, 24-27.05.2012.

A. E. Grzegorzewska ( $\bowtie) \cdot$ P. M. Wobszal

Department of Nephrology, Transplantology and Internal

Diseases, Poznań University of Medical Sciences,

49 Przybyszewskiego Blvd, 60-355 Poznań, Poland

e-mail: alicja_grzegorzewska@yahoo.com

P. M. Wobszal

e-mail:pwobsz@gmail.com

\section{A. Sowińska}

Department of Computer Science and Statistics, Poznań

University of Medical Sciences, 79 Dąbrowskiego Str,

60-529 Poznań, Poland

e-mail: ania@ump.edu.pl

\author{
A. Mostowska · P. P. Jagodziński \\ Department of Biochemistry and Molecular Biology, Poznań \\ University of Medical Sciences, 6 Święcickiego Str, \\ 60-781 Poznań, Poland \\ e-mail: amostowska@wp.pl \\ P. P. Jagodziński \\ e-mail: pjagodzi@ump.edu.pl
}

with HBV in the past (group II). In group I, 199 patients did not develop an anti-HBs titre $>10 \mathrm{IU} / \mathrm{L}$ (subgroup Ia), whereas in group II, 55 patients did not develop an anti-HBs titre $>10$ IU/L (subgroup IIa). Patients of groups I and II that developed an anti-HBs $>10$ IU/L were included into subgroups Ib and IIb, respectively. In hepatitis B vaccinated HD patients, development of a protective anti-HBs titre was positively associated with vintage of renal replacement therapy (RRT), chronic glomerulonephritis as a cause of RRT, and GA rs $568408 I L-12 A$ (OR 1.6, $95 \%$ CI 1.0-2.5, $P=0.035$ ), but a frequency distribution of this genotype between responders and non-responders was not significant when the Bonferroni correction was applied. In HBV infected HD patients, anti-HBs development was positively associated with AC rs3212227 IL-12B (OR 8.0, $95 \%$ CI 2.6-24.9, $P<0.001)$, whereas $\mathrm{HBsAg}$ positivity, AA rs3212227 $I L-12 B$ (OR 0.3, $95 \%$ CI 0.1-0.7, $P=0.007$ ), and CC rs3212227 IL-12B (OR 0.1, $95 \%$ CI 0.03-0.6, $P=0.011)$ were negative predictors of positive anti-HBs phenotype. When the Bonferroni correction was applied, if appropriate, these associations remained significant. In HD patients, the studied $I L-12$ polymorphic variants seem to be associated with the anti-HBs phenotype (a) with borderline significance for $I L-12 A$ in hepatitis B vaccinated patients, and (b) significantly for $I L-12 B$ in patients who underwent natural HBV infection.

Keywords Anti-HBs · Gene polymorphism . Hemodialysis · Infection · Interleukin-12 .

Vaccination

Abbreviations
$\begin{array}{ll}\text { ALT } & \begin{array}{l}\text { Alanine aminotransferase } \\ \text { anti-HBc }\end{array} \\ & \begin{array}{l}\text { Antibodies to core antigen of hepatitis B } \\ \text { virus }\end{array}\end{array}$

Abbreviations

ALT Alanine aminotransferase virus 
anti-HBs Antibodies to surface antigen of hepatitis B virus

anti-HCV Antibodies to hepatitis $\mathrm{C}$ virus

AST Aspartate aminotransferase

CI Confidence interval

DNA Deoxyribonucleic acid

GGT

HBV

Gamma-glutamyltranspeptidase

$\mathrm{HBsAg}$

$\mathrm{HCV}$

Hepatitis B virus

HD

Surface antigen of hepatitis B virus

HD

Hepatitis $\mathrm{C}$ virus

IL

Hemodialysis

IFN

MDR

MEIA

NA

OR

Interleukin

Interferon

Multifactor dimensionality reduction

Microparticle enzyme immunoassay

Not applicable

PCR-RFLP Polymerase chain reaction-restriction fragment length polymorphism

RNA Ribonucleic acid

RRT Renal replacement therapy

SNP Single nucleotide polymorphism

UTR Untranslated region

\section{Introduction}

Antibodies to the surface antigen of the hepatitis B virus (anti-HBs) are specific neutralizing antibodies indicative of either an immune response triggered as a result of having received a vaccine containing the surface antigen of the hepatitis B virus (HBsAg) or active immunity to the hepatitis $B$ virus (HBV) as a result of prior infection with $\mathrm{HBV}$ having $\mathrm{HBsAg}$ in its structure. Anti-HBs in the bloodstream may also result from passive immunity created by injection of hepatitis B immunoglobulin for post-exposure prophylaxis.

According to the current recommendations, protection of hemodialysis (HD) patients against $\mathrm{HBV}$ infection should include hepatitis $B$ vaccination using licensed hepatitis $\mathrm{B}$ vaccines given at $0,1,2$ and 6 months in the dose of $40 \mu \mathrm{g}$ each administered by the intramuscular route at one site. Patients who did not respond to the primary vaccine series should be revaccinated with three additional doses and retested for response [1]. The development of this advanced vaccination strategy still does not elicit the adequate anti-HBs response in $20 \% \mathrm{HD}$ vaccinees [2]. Therefore, a substantial number of HD patients is not adequately protected against HBV infection.

Natural HBV transmission to the human body leads to the appearance of specific seromarkers, among them
HBsAg, antibodies to HBV core antigen (anti-HBc), and anti-HBs. The development of anti-HBs used to be associated with the disappearance of HBsAg. Anti-HBc are established markers of current (in IgM class) or past (in IgG class) HBV infection. If anti-HBs do not appear during the HBV infection, it results either in HBsAg carrier status, which is associated with detectable HBV deoxyribonucleic acid (DNA) in about $65 \%$ of infected HD patients [3, 4], or in the occurrence of isolated anti-HBc positivity (anti$\mathrm{HBc}$ positive individuals are both $\mathrm{HBsAg}$ and anti-HBs negative), which in HD patients may be associated with detectable HBV DNA [5]. HBV replication may contribute to morbidity and mortality related to HBV-associated diseases [6-8]. Ineffective hepatitis B vaccination is predictive for the prevalence and incidence of both HBsAg [9] and anti-HBc $[10,11]$ positivity.

Interleukin (IL)-12 is a heterodimeric proinflammatory cytokine composed of a $35 \mathrm{kDa}$ light chain and a $40 \mathrm{kDa}$ heavy chain. $I L-12$ plays a key role in the regulation of the immune response to $\mathrm{HBV}$ antigens during spontaneous infection [12-14] or planned vaccination [15, 16]. IL-12 is a member of the cytokine network, which includes pro- and anti-inflammatory bioactive peptides. This network may be influenced by multiple factors, such as blood transfusions [17], stress [18], iron status [19] and many others, resulting in changes in serum levels of interleukins. The concentrations of these cytokines, among them $I L-12$, reflect actual somatic and behavioral status, whereas genotypes are not influenced by internal and external signals.

The light $(35 \mathrm{kDa})$ and heavy $(40 \mathrm{kDa})$ chains of $I L-12$ are encoded by the $I L 12 A$ and $I L 12 B$ genes, respectively. The $3^{\prime}$ untranslated regions (UTRs) influence the amount of translated protein [20], therefore the single nucleotide polymorphisms (SNPs) IL12A G $>$ A (rs568408) and IL12B $\mathrm{A}>\mathrm{C}$ (rs3212227), located in the $3^{\prime}$ UTR, are suspected in the modulation of $I L-12$ levels [21]. Polymorphisms and haplotypes in $I L-12 B$ have already been directly associated with $I L-12$ production in previous studies [22, 23]. Moreover, the number of polymorphisms located in $I L-12 B$ is limited and these SNPs display significant linkage disequilibrium [22]. Therefore, polymorphisms in the $3^{\prime}$ UTR region of $I L 12 A$ (rs568408) and IL12B (rs3212227), influencing $I L-12$ levels, might also affect the immune response to $\mathrm{HBV}$ antigens.

A recent study [24] has shown no association with $\mathrm{HBV}$ persistence and $I L-12 A$, whereas the $I L-12 B$ promoter $\mathrm{S}$ allele was associated with non-responsiveness to $\mathrm{HBV}$ vaccination [25]. Our recent studies have shown that polymorphic variants of $I L-18$ individually or jointly with polymorphic variants of $I L-12 A$ or $I L-12 B$ are associated with the development of anti-HBs in HD patients [26, 27]. It could not be distinguished from these studies [26, 27], whether there is any difference in the association between 
anti-HBs development and the examined polymorphic variants when anti-HBs are generated in response to $\mathrm{HBV}$ transmission after HBV clearance or when the protective immune humoral response is triggered by the vaccine selectively containing the $\mathrm{S}$ protein of HBsAg. This task seems to be especially meaningful in light of an earlier study showing that some inbred strains of mice that are unresponsive to protein $\mathrm{S}$ of HBsAg do produce anti-HBs when immunized with a larger surface viral protein containing S HBsAg and pre-S(1) [28]. Recombinant DNA hepatitis B vaccine containing $\mathrm{HBsAg}$ particles harbouring all three viral envelope polypeptides, the major $S$ protein and the minor Pre-S2 and Pre-S1, was shown to be more powerful in the development of anti-HBs than did standard recombinant vaccines containing only $S$ the protein [29].

The aim of our study was to perform a separate analysis of hepatitis B vaccinated and HBV infected HD patients in relation to the polymorphic variants of IL12A G $>$ A (rs568408) and IL12B A $>\mathrm{C}$ (rs3212227) and to assess whether in HD patients polymorphic variants of $I L-12$ are equally associated with the development of anti-HBs in the event of HBV vaccination or HBV infection.

\section{Materials and methods}

\section{Patients and controls}

Studies were carried out in 839 HD patients treated in 22 dialysis centers located in the Wielkopolska region of Poland. Metrical age and renal replacement therapy (RRT) vintage that are shown in the Results section are both in regards concern to the date that blood samples were collected for genotyping. HBV seromarkers (HBsAg, anti$\mathrm{HBc}$, anti-HBs) were determined in each patient at $\mathrm{HD}$ commencement. HBsAg determinations were repeated on a mandatory basis every 6 months, total anti-HBc voluntarily every $8-12$ months. All patients were vaccinated against HBV with recombinant DNA yeast-derived vaccines, composed of the S protein of HBsAg (Engerix B, GlaxoSmithKline Biologicals, Belgium; Hepavax-Gene, BIOMED SA, Poland; Euvax B, LG Chemical, South Korea) according to the rules established for HD patients [1]. An anti-HBs titre was checked after 4-8 weeks from the last vaccine dose. When an anti-HBs titre remained below $10 \mathrm{IU} / \mathrm{L}$, assumed to be non-protective in vaccinated patients [30], vaccination was repeated. The level of antiHBs wanes over the time after vaccination, so a blood test for anti-HBs was repeated in all HD patients on a mandatory basis every 6 months to determine if vaccine booster doses were required.
Patients enrolled to the study had to fulfill the following criteria:

- Treatment with HD due to end-stage renal disease,

- No signs and symptoms of acute infection with bloodborne viruses within 6 months before enrollment,

- Determined panel of HBV seromarkers sufficient for a classification of a patient to:

- HBV vaccinated group (I) without (subgroup Ia) or with (subgroup Ib) developed anti-HBs,

- HBV infected group (II) without (subgroup IIa) or with (subgroup IIb) developed anti-HBs,

- From patients who disclosed a genetic relationship only one person could participate in the study,

- Provided written consent to participate in the study.

Criteria of classification of HD patients to the aforementioned groups are presented in Table 1. Only patients with no history of acute hepatitis B and showing HBsAg and anti-HBc negative in all tests were included into group I. Therefore, there was no documentation that anti-HBs could be developed due to HBV transmission prior to immunization. Patients that were never vaccinated for hepatitis B that consistently maintained anti-HBc positivity, also showing isolated anti-HBs positivity, were considered to have been infected with HBV in the past (group II).

All of the available results for HBV seromarkers of each patient were analyzed. If a patient had an anti-HBs titre $>10 \mathrm{IU} / \mathrm{L}$ in the past and further had a decline in an antiHBs titre $<10 \mathrm{IU} / \mathrm{L}$, s/he was considered to be constitutionally able to develop anti-HBs and was included into group Ib or IIb.

Hepatitis B vaccinated or HBV infected HD patients, being also infected with hepatitis $\mathrm{C}$ virus (HCV), were included into the study when they were established as $\mathrm{HBsAg}$ responders or not responders before $\mathrm{HCV}$ transmission.

Group I included 602 patients (subgroup Ia-199, subgroup Ib-403), group II-237 patients (subgroup IIa-55, subgroup IIb-182).

Registered blood donors, qualified for blood donation according to the criteria of Polish Ministry of Health [31], served as controls for HD patients. All controls $(n=240)$ showed negative blood testing for HBsAg and HBV DNA as well as for seromarkers of infection with HCV. Unfortunately, the hepatitis B vaccination rate and an anti-HBs titre were not known in these healthy individuals.

Genotype analysis for rs568408 $3^{\prime} \mathrm{UTR}$ G $>$ A in $I L-12 A$ and $\mathrm{rs} 32122273^{\prime}$ UTR $\mathrm{A}>\mathrm{C}$ in $I L-12 B$ was performed in all patients and controls. 
Table 1 Criteria of classification of hemodialysis patients

\begin{tabular}{|c|c|c|c|c|}
\hline \multirow[t]{2}{*}{ Parameter } & \multicolumn{2}{|l|}{ Group I } & \multicolumn{2}{|l|}{ Group II } \\
\hline & Subgroup Ia & Subgroup Ib & Subgroup IIa & Subgroup IIb \\
\hline $\begin{array}{l}\text { History of } \\
\text { acute } \\
\text { hepatitis B }\end{array}$ & No & & Yes or no & \\
\hline $\mathrm{HBsAg}$ & Negative in all available results & & Negative or positi & \\
\hline Anti-HBc & Negative in all available results & & $\begin{array}{l}\text { Positive } \\
\text { in a patient wit } \\
\text { currently or in t } \\
\text { in a never hepa } \\
\text { with an anti-HB } \\
\text { confirmed by th } \\
\text { laboratories usir } \\
\text { anti-HBc detern } \\
\text { in consecutive c } \\
\text { patient without }\end{array}$ & $\begin{array}{l}\text { documented HBsAg } \\
\text { past, } \\
\text { is B vaccinated patien } \\
\text { titre }>10 \mathrm{IU} / \mathrm{L} \text {, } \\
\text { independent } \\
\text { different methods of } \\
\text { ation and maintained } \\
\text { erminations in a } \\
\text { her HBV seromarkers }\end{array}$ \\
\hline $\begin{array}{l}\text { Hepatitis B } \\
\text { vaccination }\end{array}$ & $\begin{array}{l}\text { Two full vaccination series ( } 4 \text { doubled doses of } 20 \mu \mathrm{g} \text { each } \\
\text { given at } 0-1-2-6 \text { months) or equivalent vaccine } \\
\text { summarized dose }(160 \mu \mathrm{g} \text { ) with anti-HBs titre } \leq 10 \mathrm{IU} / \mathrm{L} \\
\text { after } 4-8 \text { weeks from the last vaccine dose }\end{array}$ & $\begin{array}{l}\text { At least one } \\
\text { vaccination series }\end{array}$ & No hepatitis B va & ination \\
\hline Anti-HBs & Negative ( $\leq 10 \mathrm{IU} / \mathrm{L})$ in all available results & $\begin{array}{l}\text { Positive }(>10 \mathrm{IU} / \mathrm{L}) \\
\text { in at least one } \\
\text { confirmed result }\end{array}$ & $\begin{array}{l}\text { Negative } \\
(\leq 10 \mathrm{IU} / \mathrm{L}) \text { in } \\
\text { all available } \\
\text { results }\end{array}$ & $\begin{array}{l}\text { Positive }(>10 \mathrm{IU} / \mathrm{L}) \\
\text { in at least one } \\
\text { confirmed result }\end{array}$ \\
\hline
\end{tabular}

anti- $H B C$ antibodies to core antigen of hepatitis B virus, anti- $H B s$ antibodies to surface antigen of hepatitis B virus, $H B s A g$ surface antigen of hepatitis B virus

\section{Laboratory methods}

$\mathrm{HBV}$ and $\mathrm{HCV}$ seromarkers, as well as serum activities of liver enzymes, were determined as previously described [27]. All HBV or HCV positive results were the subject of confirmation tests.

\section{$I L-12 A$ and $I L-12 B$ genotyping}

DNA was isolated from peripheral leukocytes. The $I L-12 \mathrm{~A}$ $3^{\prime} U T R \mathrm{G}>\mathrm{A}$ (rs568408) polymorphism was genotyped by high-resolution melting curve analysis (HRM); identification of the $I L-12 B 3^{\prime} U T R$ A $>C$ (rs3212227) polymorphic variants was carried out by polymerase chain reactionrestriction fragment length polymorphism (PCR-RFLP), as previously described [27]. For quality control of the tested polymorphisms, approximately $10 \%$ of the randomly chosen samples were re-genotyped using commercial sequencing. We observed $99.9 \%$ concordance between results of PCR-RFLP analysis and sequencing.

\section{Statistical methods}

Descriptive statistics are presented as percentage for categorical variables, and median with range for continuous variables because asymmetry of distribution was shown in all but one (age in subgroup IIa) variable as tested by the Shapiro-Wilk test. The prevalence of variables was assessed by the Chi square test, the Chi square test with Yates correction, or the $\mathrm{V}$ square test, as appropriate. Continuous variables were compared using the MannWhitney U-test.

Hardy-Weinberg equilibrium was tested by the Chi square test with one degree of freedom $(P<0.01$ for significance) to compare the observed genotype frequencies to the expected ones. Power analysis was conducted employing the Fisher exact test (http://biostat.mc. vanderbilt.edu/twiki/bin/view/Main/ PowerSampleSize).

The associations between genotypes and the anti-HBs phenotype were estimated by computing the odds ratio (OR) and its $95 \%$ confidence interval $(95 \% \mathrm{CI})$. A frequency distribution of the examined genotypes was referred to that of the respective homozygous wild-type genotypes. Results of all associations were adjusted, if possible, for parameters which significantly differentiated the examined groups. Values of $P<0.05$ were judged to be significant. All probabilities were two-tailed. The $P$ value using the Bonferroni correction for multiple testing was calculated, if appropriate, and related to results of the initial statistical analysis. Logistic regression analysis was 
Table 2 The selected demographic, clinical and laboratory data of vaccinated hemodialysis patients divided into subgroups

\begin{tabular}{|c|c|c|c|}
\hline \multirow[t]{2}{*}{ Parameter } & \multicolumn{2}{|l|}{ Group I $(n=602)$} & \multirow{2}{*}{$\begin{array}{l}P \text { value for differences } \\
\text { between Ia and Ib }\end{array}$} \\
\hline & Subgroup Ia $(n=199)$ & Subgroup $\mathrm{Ib}(n=403)$ & \\
\hline Men, $n(\%$ of all $)$ & $103(51.8)$ & $228(56.6)$ & 0.296 \\
\hline Age, years & $69.6(23.8-92.5)$ & $62.8(18.6-91.7)$ & $<0.001$ \\
\hline RRT duration, years & $1.0(0.03-11.6)$ & $2.8(0.003-26.1)$ & $<0.001$ \\
\hline Diabetic nephropathy, $n$ (\% of all) & $72(36.2)$ & $102(25.3)$ & 0.007 \\
\hline Chronic glomerulonephritis, n (\% of all) & $11(5.5)$ & $78(19.4)$ & $<0.001$ \\
\hline Hypertensive nephropathy, $n$ ( $\%$ of all) & $40(20.1)$ & $67(16.6)$ & 0.308 \\
\hline Chronic tubulointerstitial nephritis, $n$ ( $\%$ of all) & $18(9.0)$ & $35(8.7)$ & 0.880 \\
\hline An anti-HBs titre $>10 \mathrm{IU} / \mathrm{L}$ & - & $403(100 \%)$ & NA \\
\hline Positive anti-HCV, $n$ ( $\%$ of all) & $11(5.5)$ & $37(9.2)$ & 0.150 \\
\hline $\begin{array}{l}\text { Positive both anti-HCV and HCV RNA } \\
\text { ( } n, \% \text { of all anti-HCV positive) }\end{array}$ & $5(45.5)$ & $25(67.6)$ & 0.288 \\
\hline ALT (IU/L) & $13(0.6-126)$ & $13(2-209)$ & 0.222 \\
\hline AST (IU/L) & $14(5-97)$ & $15(4-177)$ & 0.309 \\
\hline GGT (IU/L) & $30(5-308)$ & $25(0-472)$ & 0.590 \\
\hline
\end{tabular}

Continuous variables are expressed as median and range. Significant results are indicated using bold font

$A L T$ alanine aminotransferase, anti-HBs antibodies to surface antigen of hepatitis B virus, anti-HCV antibodies to hepatitis $\mathrm{C}$ virus, $A S T$ aspartate aminotransferase, GGT gamma-glutamyltranspeptidase, $H C V R N A$ ribonucleic acid of hepatitis $\mathrm{C}$ virus, $N A$ not applicable, $R R T$ renal replacement therapy

used to show variables associated with anti-HBs phenotype concomitantly with the examined polymorphic variant. To address the possibility of a gene-gene interaction effect between the analyzed SNPs, a nonparametric and genetic model-free multifactor dimensionality reduction (MDR) approach was used [32].

Ethical issues

This study was approved by the Institutional Review Board of Poznań University of Medical Sciences, Poland.

\section{Results}

Results of HBV vaccinated HD patients (subgroups Ia and $\mathrm{Ib}$ )

The selected demographic, clinical and laboratory data of vaccinated HD patients are shown in Table 2. All patients were Caucasian.

Distribution of $I L-12 A$ and $I L-12 B$ polymorphic variants in subgroups Ia and Ib was in agreement with HardyWeinberg equilibrium. In group I, differences of genotype frequencies were adjusted, if possible, for age, RRT vintage, and diabetic nephropathy or chronic glomerulonephritis as causes of RRT.

In the logistic regressions that included gender, age, RRT vintage, kidney diseases, liver enzymes, anti-HCV, and polymorphic variants of $I L-12 A$, there was a positive association of anti-HBs development in response to hepatitis B vaccination with concurrently RRT vintage (OR 1.3, $95 \%$ CI 1.2-1.5, $P<0.001)$, chronic glomerulonephritis (OR 2.6, $95 \%$ CI $1.2-5.4, P=0.012$ ), and GA $I L-12 A$ (OR 1.6, $95 \%$ CI 1.0-2.5, $P=0.035$ ); a negative association was shown with age (OR 0.98, $95 \%$ CI $0.97-1.0$, $P=0.018)(P<0.001$ for the significance of this model $)$. Similar results were obtained if anti-HCV were replaced in the model by HCV RNA. If a frequency distribution of the GA rs568408 IL-12A variant was related to that of the homozygous wild-type genotype GG rs568408 IL- $12 A$, patients bearing GA had a 1.6-fold higher chance to respond to the HBV vaccine than patients having the wildtype genotype (sample power $74 \%$ ). However, when the Bonferroni correction was applied this result was not significant (Table 3).

Statistical evidence for association of the $I L-12 A$ polymorphism with anti-HBs development in response to hepatitis B vaccination is summarized in Table 4 .

There was no association between the $I L-12 B$ polymorphism and anti-HBs phenotype (Table 3).

Results of HBV infected HD patients (subgroups IIa and IIb)

The selected demographic, clinical and laboratory data of infected HD patients are shown in Table 5. All patients were Caucasian. 
Table $3 I L-12$ polymorphisms in hemodialysis non-responders to hepatitis B vaccine (subgroup Ia) and hemodialysis responders to hepatitis B vaccine (subgroup Ib) with the development of antibodies to surface antigen of hepatitis B virus

${ }^{a}$ Odds ratio (OR) after adjustment for age, renal replacement therapy (RRT) vintage, and diabetic nephropathy or chronic glomerulonephritis as causes of RRT

b Non-significant after the Bonferroni correction for multiple comparisons $(P>0.017)$

\begin{tabular}{|c|c|c|c|c|}
\hline Genotype & Subgroup Ia $(n=199) n(\%)$ & Subgroup $\mathrm{Ib}(n=403) n(\%)$ & OR $(95 \% \mathrm{CI})$ & $P$ value \\
\hline \multicolumn{5}{|l|}{$I L-12 A$} \\
\hline GG & $152(76.4)$ & $275(68.2)$ & Referent & \\
\hline GA & $40(20.1)$ & $115(28.5)$ & $1.6(1.0-2.5)^{\mathrm{a}}$ & $0.033^{\mathrm{b}}$ \\
\hline AA & $7(3.5)$ & $13(3.2)$ & $1.0(0.6-1.7)^{\mathrm{a}}$ & 0.984 \\
\hline GA/AA & $47(23.6)$ & $128(31.8)$ & $1.5(1.0-2.3)^{\mathrm{a}}$ & $0.048^{\mathrm{b}}$ \\
\hline AA & $7(3.5)$ & $13(3.2)$ & Referent & \\
\hline GA/GG & $192(96.5)$ & $390(96.8)$ & $1.2(0.4-3.2)^{\mathrm{a}}$ & 0.783 \\
\hline Allele G & $344(86.4)$ & $665(82.5)$ & Referent & \\
\hline Allele A & $54(13.6)$ & $141(17.5)$ & $1.4(1.0-1.9)$ & 0.096 \\
\hline \multicolumn{5}{|l|}{$I L-12 B$} \\
\hline AA & $121(60.8)$ & $231(57.3)$ & Referent & \\
\hline $\mathrm{AC}$ & $74(37.2)$ & $160(39.7)$ & $1.0(0.7-1.5)^{\mathrm{a}}$ & 0.876 \\
\hline $\mathrm{CC}$ & $4(2.0)$ & $12(3.0)$ & $1.1(0.6-2.1)^{\mathrm{a}}$ & \\
\hline $\mathrm{AC} / \mathrm{CC}$ & $78(39.2)$ & $172(42.7)$ & $1.3(0.4-4.5)^{\mathrm{a}}$ & 0.626 \\
\hline $\mathrm{CC}$ & $4(2.0)$ & $12(3.0)$ & Referent & \\
\hline AC/AA & $195(98.0)$ & $391(97.0)$ & $0.8(0.2-2.6)^{\mathrm{a}}$ & 0.660 \\
\hline AlleleA & $319(79.6)$ & $622(77.2)$ & Referent & \\
\hline Allele C & $82(20.4)$ & $184(22.8)$ & $1.2(0.9-1.6)$ & 0.387 \\
\hline
\end{tabular}

Table 4 Statistical evidence for association of $I L-12 A$ polymorphism with anti-HBs development in response to hepatitis $B$ vaccination

\begin{tabular}{|c|c|c|c|}
\hline \multirow[t]{2}{*}{$\begin{array}{l}I L-12 A \\
\text { polymorphism }\end{array}$} & \multicolumn{2}{|c|}{$\begin{array}{l}\text { Adjusted reference to homozygous } \\
\text { wilde-type genotype }\end{array}$} & \multirow{2}{*}{$\begin{array}{l}\text { The } \\
\text { logistic } \\
\text { regression } \\
(\mathrm{OR}, 95 \% \\
\mathrm{CI}, P)\end{array}$} \\
\hline & $\begin{array}{l}\text { Without the } \\
\text { Bonferroni } \\
\text { correction } \\
(\mathrm{OR}, 95 \% \\
\text { CI, } P)\end{array}$ & $\begin{array}{l}\text { With the } \\
\text { Bonferroni } \\
\text { correction } \\
(\mathrm{OR}, 95 \% \\
\text { CI, } P \text { ) }\end{array}$ & \\
\hline GG & na & na & ns \\
\hline GA & $1.6,1.0-2.5,0.033$ & ns & $\begin{array}{l}1.6, \\
1.0-2.5 \\
0.035\end{array}$ \\
\hline AA & ns & ns & ns \\
\hline GA/AA & $1.5,1.0-2.3,0.048$ & ns & ns \\
\hline
\end{tabular}

na not applicable, $n s$ non-significant

Distribution of $I L-12 A$ and $I L-12 B$ polymorphic variants did not show deviation from Hardy-Weinberg equilibrium with exception of subgroup IIa in respect to $I L-12 B$ $(P=0.0002)$. Subgroup IIa also differed in $I L-12 B$ genotype frequencies from controls $(P=0.016)$, which showed the distribution of the $I L-12 B$ genotype in concordance with Hardy-Weinberg equilibrium and with a previously described control Caucasian population [22].

There was no association between the $I L-12 \mathrm{~A}$ polymorphism and anti-HBs phenotype (Table 6).

In the best regression models that included gender, age, RRT vintage, kidney diseases, liver enzymes, HBsAg, anti-
HCV, history of hepatitis $\mathrm{B}$, and polymorphic variants of $I L-12 B(P<0.001$ for a significance of each model $)$, there was a positive association of anti-HBs development in response to hepatitis $\mathrm{B}$ infection with the AC polymorphic variant of $I L-12 B$ (OR 8.0, $95 \%$ CI 2.6-24.9, $P<0.001$ ); negative associations were shown with $\mathrm{HBs} A g$ positivity (OR 0.02, $95 \%$ CI $0.003-0.07, P<0.001$ ) and the CC polymorphic variant of $I L-12 B$ (OR $0.1,95 \%$ CI $0.03-0.06, P=0.011)$. Similar results were obtained if anti-HCV were replaced in the model by HCV RNA, and HBsAg by HBV DNA.

In group II, results were adjusted, if possible, for HBsAg and chronic glomerulonephritis as a cause of RRT. If a frequency distribution of the examined polymorphisms was related to that of the homozygous wild-type genotype and the Bonferroni correction was applied, AC rs3212227 IL$12 B$ was positively associated with anti-HBs development (sample power $99.4 \%$ ), whereas CC rs3212227 IL-12B was predictive for negative anti-HBs phenotype (sample power $69.5 \%$, Table 6 ).

Selected dichotomized and combined effects of the $I L$ 12 polymorphisms are presented in Tables 7 and 8. Compared to any other genotypes, GG rs568408 IL-12A and AC rs3212227 $I L-12 B$ were associated with positive anti-HBs phenotype (sample power $90.8 \%$ ), whereas both GG rs568408 IL-12A and CC rs3212227 IL-12B (sample power $74.2 \%$ ) or both AA rs568408 IL-12A and AA rs3212227 $I L-12 B$ (sample power $66.0 \%$ ) were related to the negative anti-HBs phenotype (Table 7). When pairs of genotypes were referred to the other selected genotype pair, patients bearing both GG rs568408 IL-12A and CC rs3212227 IL- 
Table 5 The selected demographic, clinical and laboratory data of infected hemodialysis patients divided into subgroups IIa and IIb with comparison of results to those of vaccinated patients (subgroups Ia and Ib)

\begin{tabular}{|c|c|c|c|c|c|}
\hline \multirow[t]{2}{*}{ Parameter } & \multicolumn{2}{|c|}{ Group II $(n=237)$} & \multirow{2}{*}{$\begin{array}{l}P \text { value for } \\
\text { differences } \\
\text { between } \\
\text { IIa and IIb }\end{array}$} & \multirow{2}{*}{$\begin{array}{l}P \text { value for } \\
\text { differences } \\
\text { between } \\
\text { Ia and IIa }\end{array}$} & \multirow{2}{*}{$\begin{array}{l}P \text { value for } \\
\text { differences } \\
\text { between } \\
\mathrm{Ib} \text { and } \mathrm{IIb}\end{array}$} \\
\hline & $\begin{array}{l}\text { Subgroup IIa } \\
(n=55)\end{array}$ & $\begin{array}{l}\text { Subgroup IIb } \\
(n=182)\end{array}$ & & & \\
\hline Men, $n(\%$ of all $)$ & $35(63.6)$ & $101(55.5)$ & 0.351 & 0.128 & 0.857 \\
\hline Age, years & $59.3(19.3-87.7)$ & $61.7(18.9-90.4)$ & 0.143 & $<0.001$ & 0.691 \\
\hline RRT duration, years & $3.6(0.1-24.2)$ & $2.5(0.05-26.0)$ & 0.086 & $<0.001$ & 0.179 \\
\hline Diabetic nephropathy, $n$ (\% of all) & $9(16.4)$ & $53(29.1)$ & 0.079 & 0.005 & 0.363 \\
\hline Chronic glomerulonephritis, $n$ ( $\%$ of all) & $17(30.9)$ & $30(16.5)$ & $\mathbf{0 . 0 3 2}$ & $<0.001$ & 0.423 \\
\hline Hypertensive nephropathy, $n$ ( $\%$ of all) & $5(9.1)$ & $24(13.2)$ & 0.490 & 0.072 & 0.326 \\
\hline Chronic tubulointerstitial nephritis, $n$ (\% of all) & $6(10.9)$ & $18(9.9)$ & 0.802 & 0.613 & 0.643 \\
\hline History of acute hepatitis $\mathrm{B}, n$ ( $\%$ of all) & $5(9.1)$ & $10(5.5)$ & 0.568 & NA & NA \\
\hline Positive HBsAg, $n$ ( $\%$ of all) & $20^{\mathrm{a}}(36.4)$ & $4^{\mathrm{b}}(2.2)$ & $<0.001$ & NA & NA \\
\hline Positive HBV DNA, $n$ ( $\%$ of all) & $18(32.7)$ & $4(2.2)$ & $<0.001$ & NA & NA \\
\hline Positive anti-HBc, n (\% of all) & $55(100 \%)$ & $182(100 \%)$ & NA & NA & NA \\
\hline Isolated positive anti-HBc, $n$ ( $\%$ of all anti-HBc positive) & $35(63.6)$ & - & NA & NA & NA \\
\hline An anti-HBs titre $>10 \mathrm{IU} / \mathrm{L}$ & - & $182(100 \%)$ & NA & NA & 1.000 \\
\hline Positive anti-HCV, $n$ (\% of all) & $13(23.6)$ & $37(20.3)$ & 0.577 & $<0.001$ & $<0.001$ \\
\hline Positive HCV RNA $n$ ( $\%$ of all anti-HCV positive) & $8(61.5)$ & $24(64.9)$ & 1.000 & 0.682 & 1.000 \\
\hline ALT (IU/L) & $18(4-53)$ & $14(0-195)$ & 0.295 & 0.011 & 0.372 \\
\hline AST (IU/L) & $16(8-81)$ & $16(1-152)$ & 0.224 & 0.024 & 0.389 \\
\hline GGT (IU/L) & $23(-7284)$ & $25(0-692)$ & 0.762 & 0.915 & 0.958 \\
\hline
\end{tabular}

Continuous variables are expressed as median and range. Significant results are indicated using bold font

$A L T$ alanine aminotransferase, anti-HBc antibodies to core antigen of hepatitis B virus, anti-HBs antibodies to surface antigen of hepatitis B virus, anti-HCV antibodies to hepatitis $\mathrm{C}$ virus, $A S T$ aspartate aminotransferase, $G G T$ gamma-glutamyltranspeptidase, $H B V$ hepatitis $\mathrm{B}$ virus, $H B s A g$ surface antigen of hepatitis B virus, $H B V D N A$ deoxyribonucleic acid of hepatitis B virus, $H C V R N A$ ribonucleic acid of hepatitis $\mathrm{C}$ virus, $N A$ not applicable, $R R T$ renal replacement therapy

$12 B$ had a near-17-times lower chance to develop anti-HBs compared to patients having both GG rs568408 IL-12A and AC rs3212227 IL-12B (sample power $91.9 \%$, Table 8).

The MDR analysis revealed a borderline statistical significance between subgroups IIa and IIb. In this case, the testing balanced accuracy for the analysed 2-locus model was 0.582 , cross validation consistency $100 \%$ and $P$ value derived from the 1,000 -fold permutation test was 0.082 .

Statistical evidence for an association of the $I L-12 B$ polymorphism with anti-HBs development in response to hepatitis B virus infection is summarized in Table 9.

\section{HCV infection in HD patients}

HD patients with an active HCV infection were equally distributed among individuals that developed anti-HBs and those that did not develop anti-HBs. This was the case for both vaccinated (Table 2) and infected (Table 5) HD patients. The logistic regression analysis did not reveal a significant predictive value of anti-HCV or HCV RNA for anti-HBs development in hepatitis B vaccinated or infected patients.
Comparison of results of HD patients that did not develop anti-HBs despite HBV vaccination or infection (subgroups Ia and IIa)

Comparison of the $I L-12 A$ and $I L-12 B$ polymorphic variants in subgroups Ia and IIa revealed that a higher frequency of allele $\mathrm{G}$ rs568408 $I L-12 A$ remained associated with non-responsiveness to hepatitis $B$ vaccination (OR $0.5,95 \%$ CI $0.3-0.9, P=0.025$ ), whereas the negative anti-HBs phenotype after $\mathrm{HBV}$ transmission remained associated with a higher frequency of CC rs3212227 IL$12 B$ (adjusted OR 4.6, $95 \%$ CI 1.0-21.1, $P=0.047$ ) and lower frequencies of AC (adjusted OR 0.4, $95 \%$ CI $0.2-1.0, P=0.039$ ) and AC/AA (adjusted OR 0.2, $95 \%$ CI $0.05-1.0, P=0.047$ ) compared to any other examined genotypes of $I L-12 B$.

Comparison of results of HD patients that developed anti-HBs as a result of HBV vaccination or infection (subgroups $\mathrm{Ib}$ and $\mathrm{IIb}$ )

Comparison of subgroups $\mathrm{Ib}$ and $\mathrm{IIb}$ in respect to the $I L$ $12 A$ and $I L-12 B$ polymorphic variants showed that patients 
Table $6 I L-12$ polymorphisms in hemodialysis non-responders to hepatitis B virus (HBV) transmission (subgroup IIa) and hemodialysis responders to HBV transmission (subgroup IIb) with the development of antibodies to surface antigen of HBV

a Odds ratio (OR) after adjustment for HBV surface antigen and chronic glomerulonephritis as a cause of renal replacement therapy

b Significant after the Bonferroni correction for multiple comparisons $(P<0.017)$

${ }^{c}$ Non-significant after the Bonferroni correction for multiple comparisons $(P>0.017)$

\begin{tabular}{lcclc}
\hline Genotype & $\begin{array}{l}\text { Subgroup IIa } \\
(n=55) n(\%)\end{array}$ & $\begin{array}{l}\text { Subgroup IIb } \\
(n=182) n(\%)\end{array}$ & OR (95\% CI) & $P$ value \\
\hline$I L-12 A$ & & & & \\
GG & $34(61.8)$ & $130(71.4)$ & Referent & \\
GA & $17(30.9)$ & $48(26.4)$ & $1.0(0.4-2.2)^{\mathrm{a}}$ & 0.954 \\
AA & $4(7.3)$ & $4(2.2)$ & $0.6(0.2-1.3)^{\mathrm{a}}$ & 0.182 \\
GA/AA & $21(38.2)$ & $52(28.6)$ & $0.8(0.4-1.8)^{\mathrm{a}}$ & 0.660 \\
AA & $4(7.3)$ & $4(2.2)$ & Referent & \\
GA/GG & $51(92.7)$ & $178(97.3)$ & $3.1(0.6-16.4)^{\mathrm{a}}$ & 0.177 \\
Allele G & $85(77.3)$ & $308(84.6)$ & Referent & \\
Allele A & $25(22.7)$ & $56(15.4)$ & $0.62(0.4-1.0)$ & 0.083 \\
$I L-12 B$ & & & & \\
AA & $39(70.9)$ & $107(58.8)$ & Referent & \\
AC & $9(16.4)$ & $71(39.0)$ & $5.7(1.9-17.2)^{\mathrm{a}}$ & $0.002^{\mathrm{b}}$ \\
CC & $7(12.7)$ & $4(2.2)$ & $0.2(0.06-0.8)$ & $0.015^{\mathrm{b}}$ \\
AC/CC & $16(29.1)$ & $75(41.2)$ & $2.7(1.1-6.2)^{\mathrm{a}}$ & $0.022^{\mathrm{c}}$ \\
CC & $7(12.7)$ & $4(2.2)$ & Referent & \\
AC/AA & $48(87.3)$ & $178(97.8)$ & $7.0(1.7-28.7)^{\mathrm{a}}$ & 0.006 \\
Allele A & $87(79.1)$ & $285(78.3)$ & Referent & \\
Allele C & $23(20.9)$ & $79(21.7)$ & $1.0(0.6-1.8)$ & 0.896 \\
\hline
\end{tabular}

Table 7 Selected dichotomized effects of the $I L-12 A$ rs568408 and $I L-12 B$ rs3212227 polymorphisms in infected hemodialysis patients

\begin{tabular}{|c|c|c|c|c|}
\hline Genotypes & $\begin{array}{l}\text { Group IIa } \\
(n=55), \\
n(\%)\end{array}$ & $\begin{array}{l}\text { Group IIb } \\
(n=182), \\
n(\%)\end{array}$ & $\begin{array}{l}\text { OR } \\
(95 \% \mathrm{CI})\end{array}$ & $P$ value \\
\hline All other genotypes & $48(87.3)$ & $129(70.9)$ & Referent & \\
\hline $\begin{array}{c}\text { rs } 568408 \mathrm{GG} \text { and } \\
\text { rs } 3212227 \mathrm{AC}\end{array}$ & $7(12.7)$ & $53(29.1)$ & $\begin{array}{l}4.0 \\
\quad(1.3-11.9)^{\mathrm{a}}\end{array}$ & 0.012 \\
\hline All other genotypes & $53(96.4)$ & $181(99.5)$ & Referent & \\
\hline $\begin{array}{l}\text { rs568408 GG and } \\
\text { rs } 3212227 \text { CC }\end{array}$ & $2(3.6)$ & $1(0.5)$ & $\begin{array}{l}0.2 \\
\quad(0.03-0.8)^{\mathrm{a}}\end{array}$ & 0.025 \\
\hline All other genotypes & $53(96.4)$ & $181(99.5)$ & Referent & \\
\hline $\begin{array}{c}\text { rs568408 AA and } \\
\text { rs3212227 AA }\end{array}$ & $2(3.6)$ & $1(0.5)$ & $\begin{array}{l}0.09 \\
\quad(0.008-1.0)^{\mathrm{a}}\end{array}$ & 0.049 \\
\hline
\end{tabular}

${ }^{a}$ Odds ratio (OR) after adjustment for HBV surface antigen and chronic glomerulonephritis as a cause of renal replacement therapy

who developed anti-HBs in response to hepatitis $\mathrm{B}$ vaccination showed higher frequencies of GA rs568408 IL-12A (adjusted OR 2.4, $95 \%$ CI 1.2-4.9, $P=0.015$ ) and GA/ AA (adjusted OR 2.5, $95 \%$ CI 1.3-5.0, $P=0.007$ ), and a lower frequency of GG rs568408 IL-12A (adjusted OR 0.4, $95 \%$ CI $0.2-0.8, P=0.007)$ compared to any other examined genotypes of $I L-12 A$.

\section{Discussion}

Gene polymorphisms of many cytokines have been established independently as being associated with a response to inoculation with the hepatitis B vaccine [25, 33-36] or with
HBV clearance after natural infection [24, 37-42]. Our study suggests that cytokine gene polymorphisms associated with a positive anti-HBs phenotype may be different in the case of vaccination than those shown in the case of HBV infection.

\section{$I L-12$ polymorphism in vaccinated HD patients}

The presence of deficient Th1-like cells is mentioned among the causes of non-responsiveness to hepatitis B vaccination [43-45]. IL-12 is a Th1 response agonist. Peripheral blood mononuclear cells from high responders to $\mathrm{HBV}$ vaccines show an elevated production of $I L-2, I L$ 12, and interferon (IFN)-gamma [45, 46]. In dialysis patients, however, the deficit of IFN-gamma has been noted, despite increased levels of serum $I L-12$ [47] or plasma free IL-18 [48]. These findings suggest the importance of proper genetic regulation of cytokine production and function in uremic patients.

In this study, multiple statistical analyses, with included a calculation of OR with $95 \% \mathrm{CI}$, adjustment for possible confounding variables and logistic regression analysis, indicated that GA rs568408 IL-12A may be the probable polymorphic variant individually associated with anti-HBs development in vaccinated HD patients. An application of the Bonferroni correction for multiple testing showed, however, that the association of GA $I L-12 A$ with the antiHBs phenotype is too weak to be significant after correction. Although the Bonferroni correction is widely used, there is a criticism to this method [49] and not all authors 
Table 8 Selected combined effects of the $I L-12 A$ rs568408 and $I L$ $12 B$ rs 3212227 polymorphisms in infected hemodialysis patients

\begin{tabular}{|c|c|c|c|c|}
\hline Genotypes & $\begin{array}{l}\text { Group IIa } \\
(n=55) \\
\text { Frequency } \\
(\%)\end{array}$ & $\begin{array}{l}\text { Group IIb } \\
(n=182) \\
\text { Frequency } \\
(\%)\end{array}$ & OR $(95 \% \mathrm{CI})$ & $P$ value \\
\hline $\begin{array}{l}\text { rs568408 } \\
\text { GG and } \\
\text { rs3212227 } \\
\text { AA }\end{array}$ & $24(43.6)$ & 74 (40.7) & Referent & \\
\hline $\begin{array}{l}\text { rs568408 } \\
\text { GG and } \\
\text { rs } 3212227 \\
\text { AC }\end{array}$ & 7 (12.7) & $53(29.1)$ & $\begin{array}{l}4.6 \\
\quad(1.3-16.5)^{\mathrm{a}}\end{array}$ & $0.019^{\mathrm{c}}$ \\
\hline $\begin{array}{l}\text { rs568408 } \\
\text { GG and } \\
\text { rs3212227 } \\
\text { AC }\end{array}$ & 7 (12.7) & $53(29.1)$ & Referent & \\
\hline $\begin{array}{l}\text { rs568408 } \\
\text { GG and } \\
\text { rs } 3212227 \\
\text { CC }\end{array}$ & $4(7.3)$ & $3(1.6)$ & $\begin{array}{l}0.06 \\
\quad(0.008-0.4)^{\mathrm{a}}\end{array}$ & $0.005^{\mathrm{b}}$ \\
\hline $\begin{array}{l}\text { rs568408 } \\
\text { AA and } \\
\text { rs3212227 } \\
\text { AA }\end{array}$ & $2(3.6)$ & $1(0.5)$ & $0.5(0.3-0.8)^{\mathrm{a}}$ & $0.009^{\mathrm{c}}$ \\
\hline
\end{tabular}

${ }^{\text {a }}$ Odds ratio (OR) after adjustment for $\mathrm{HBV}$ surface antigen and chronic glomerulonephritis as a cause of renal replacement therapy

b Significant after the Bonferroni correction for multiple comparisons $(P<0.006)$

c Non-significant after the Bonferroni correction for multiple comparisons $(P>0.006)$

Table 9 Statistical evidence for association of $I L-12 B$ polymorphism with anti-HBs development in response to hepatitis B virus infection

\begin{tabular}{|c|c|c|c|}
\hline \multirow[t]{2}{*}{$\begin{array}{l}I L-12 B \\
\text { polymorphism }\end{array}$} & \multicolumn{2}{|c|}{$\begin{array}{l}\text { Adjusted reference to homozygous } \\
\text { wilde-type genotype }\end{array}$} & \multirow{2}{*}{$\begin{array}{l}\text { The logistic } \\
\text { regression } \\
(\mathrm{OR}, 95 \% \\
\mathrm{CI}, P)\end{array}$} \\
\hline & $\begin{array}{l}\text { Without the } \\
\text { Bonferroni } \\
\text { correction (OR, } \\
95 \% \text { CI, } P \text { ) }\end{array}$ & $\begin{array}{l}\text { With the } \\
\text { Bonferroni } \\
\text { correction (OR, } \\
95 \% \mathrm{CI}, P)\end{array}$ & \\
\hline AA & na & na & $\begin{array}{l}0.3,0.1-0.7 \\
0.007\end{array}$ \\
\hline $\mathrm{AC}$ & $\begin{array}{l}5.7,1.9-17.2 \\
0.002\end{array}$ & $\begin{array}{l}5.7,1.9-17.2 \\
0.006\end{array}$ & $\begin{array}{l}8.0,2.6-24.9 \\
<0.001\end{array}$ \\
\hline $\mathrm{CC}$ & $\begin{array}{l}0.2,0.06-0.8 \\
0.015\end{array}$ & $\begin{array}{l}0.2,0.06-0.8 \\
0.045\end{array}$ & $\begin{array}{l}0.1,0.03-0.6 \\
0.011\end{array}$ \\
\hline $\mathrm{AC} / \mathrm{CC}$ & $\begin{array}{l}2.7,1.1-6.2 \\
0.022\end{array}$ & ns & $\begin{array}{l}3.3,1.4-7.8 \\
0.007\end{array}$ \\
\hline
\end{tabular}

na not applicable, $n s$ non-significant

are willing to use it in genetic studies [25]. Further studies with the inclusion of more patients may reach a statistical significance with the Bonferroni correction and may elucidate the significance of the association between rs568408
$I L-12 A$ and a response to the hepatitis B vaccine. To our knowledge, we took the first step in this analysis.

In 2004 , the $I L-12 B$ promoter $\mathrm{S}$ allele was associated with the non-responsiveness to hepatitis $\mathrm{B}$ vaccination, whereas the promoter L allele, $3^{\prime}$ UTR A and $3^{\prime}$ UTR C were not associated with the responder/non-responder phenotype. The heterozygosity of the $I L-12 B$ promoter was a significant contributor to the non-responder phenotype [25]. In our study $I L-12 B$ rs3212227 $3^{\prime}$ UTR A $>C$ was not individually associated with the responder/non-responder phenotype after hepatitis $B$ vaccination.

It is worth mentioning that HD patients frequently exhibit a deteriorated clinical status due to uremic, dialysis-related, and incidental complications. Hepatitis B vaccination is being performed (and repeated as needed) in the most optimal clinical status of each individual HD patient. Moreover, if the clinical status of a hepatitis B vaccine non-responder improves significantly, a booster dose is given by many clinicians, despite a previous full vaccination series in these patients. This practice may explain why the positive anti-HBs phenotype is associated with longer RRT vintage [50, this study]. Additionally, hepatitis B vaccine responders were younger and the prevalence of diabetic nephropathy was less frequent in this group, whereas chronic glomerulonephritis as a cause of RRT was more frequent. Patients dialyzed due to primary renal disease are usually in much better general condition than patients suffering from multi-organ diseases, such as diabetes mellitus. Older age, shorter RRT vintage, and diabetes mellitus are well-known risk factors associated with non-responsiveness to hepatitis B vaccination [50-52]. To decrease the impact of confounding variables on the results of genotype distribution analysis, OR were adjusted for age, RRT vintage, and the main causes of RRT. There were no differences in gender distribution between responders and non-responders, as shown in previous studies [53, 54]. Infection with HCV was also documented as a probable cause of hepatitis B vaccination failure [55], but in this study we did not observe a significant influence of HCV infection on antiHBs development, because patients were established as responders or non-responders prior to $\mathrm{HCV}$ infection. Furthermore, it has been shown that HCV patients secrete normal amounts of $I L-12$ [46].

Theoretically, genetic investigations could help in the development of improved hepatitis B vaccines that may eventually reduce the proportion of vaccine failures [56]. The use of exogenous $I L-12$ as an adjuvant to augment anti-HBs development in response to hepatitis B vaccines has previously been discussed [46, 57]. Our data do not provide clear confirmatory evidence that such an action at the genetic level could be evidently helpful in the case of IL-12 polymorphic variants. 


\section{$I L-12$ polymorphism in infected HD patients}

An increase of serum $I L-12$ level was associated with more effective HBV DNA clearance in patients with chronic hepatitis $\mathrm{B}$ [58], but no association with HBV persistence and $I L-12 A$ exon $7+6400 \mathrm{C}>\mathrm{T},+6624 \mathrm{G}>\mathrm{A}, 3^{\prime} \mathrm{UTR}$ $+7003 \mathrm{~T}>\mathrm{C}$ SNPs and haplotype of $I L-12 A+6400 /+6624 /$ +7003 was shown in the study by Park et al. [24]. In our study, the $I L-12 A$ rs568408 $3^{\prime} \mathrm{UTR}$ G $>$ A was not individually associated with anti-HBs development after $\mathrm{HBV}$ transmission. Therefore, the $I L-12 A$ polymorphism seems not to be involved in HBV elimination and development of protective anti-HBs. Different results were shown in the case of the $I L-12 B$ rs3212227 $3^{\prime}$ UTR A $>C$ : the AC genotype of $I L-12 B$ was associated with a positive anti-HBs phenotype after HBV infection in HD patients. Individuals heterozygous in TaqI RFLP at position 1188 in the $3^{\prime}$ URT of the $I L-12 B$ p40 gene (rs3212227) showed intermediate secretion of $I L-12$ p70 after stimulation of monocytes with Staphylococcus aureus strain Cowan and IFN-gamma compared to homozygous individuals [23]. Dichotomized and combined effects of $I L-12 A$ and $I L-12 B$ genotypes confirm that $I L-12 B$ polymorphic variants have priority in the determination of anti-HBs phenotype in HBV infected HD patients.

The deviation of rs3212227 IL-12B polymorphic variants from Hardy-Weinberg equilibrium in $\mathrm{HBV}$ infected HD patients of subgroup IIa needs to be discussed. The $I L-12 B$ polymorphism was consistent with Hardy-Weinberg equilibrium in subgroup IIb and controls. This may suggest that significant differences in the characteristics of subgroups IIa and IIb could be involved in the observed discrepancy. As expected from the natural course of $\mathrm{HBV}$ infection, anti-HBc positive patients that did not develop anti-HBs are more frequently HBsAg/HBV DNA positive compared to patients with developed protective anti-HBs. The coexistence of positive HBsAg and anti-HBs was described for 9-21\% of chronic HBV carriers [59, 60]. In our study, this coexistence occurred in about $17 \%$. Subgroup IIa included also a higher percentage of patients with chronic glomerulonephritis compared to subgroup IIb. As already mentioned, the former group also showed a higher prevalence of persistent $\mathrm{HBV}$ infection as indicated by the positive HBV DNA tests. Glomerulonephritis is an important extrahepatic manifestation of chronic $\mathrm{HBV}$ infection [61], and this etiology was probable also in the examined HBV DNA positive patients, especially considering that in the Wielkopolska region of Poland the majority $(82.1 \%)$ of $\mathrm{HBsAg}$ positive HD patients underwent $\mathrm{HBV}$ infection prior to dialysis commencement [62]. Therefore, these factors (HBsAg/HBV DNA positivity, chronic glomerulonephritis prevalence) are closely related to the type of manifestation of $\mathrm{HBV}$ infection, and the heterogeneity of both subgroups in this respect is a consequence of patients' categorization as anti-HBs positive or negative. Interestingly, significant gender differences did not occur between $\mathrm{HBV}$ infected patients with either the positive or negative anti-HBs phenotype. In most human populations, women are more likely than men to produce anti-HBs in response to $\mathrm{HBV}$ vaccination [63]. HBV infected women receiving dialysis treatment also developed anti-HBs more frequently than men [64]. Isolated anti-HBc positivity seems not to be gender-dependent [65, 66]. HBV infected HD patients without developed anti-HBs (subgroup IIa) had predominantly isolated anti-HBc positivity $(63.6 \%)$, therefore the higher prevalence of men $(63.6 \%)$ in this group did not reach significance in comparison with men that developed anti-HBs (55.5\%, subgroup IIb).

Additionally, subgroup IIa was small, because the selection criteria for inclusion into it were very specific. Until the year 2009 in Poland, when the results of anti-HBc testing were predominantly not known, HBsAg negative/ anti-HBc positive patients were hepatitis $\mathrm{B}$ vaccinated using a standard procedure. Because patients with isolated anti-HBc positivity may develop anti-HBs in some cases in response to vaccination $[67,68]$, we have qualified to group II only patients who were not vaccinated to be sure that the immune response is affected only by natural infection and not vaccination. Moreover, to find individuals who are not vaccinated for HBV will become more difficult each year in Poland, because all newborns are vaccinated on a mandatory basis. On the other hand, sample power frequently exceeded $80 \%$ in comparisons between subgroups IIa and IIb in respect to the rs3212227 IL-12B polymorphic variants. All of these facts may suggest that the lack of agreement with Hardy-Weinberg equilibrium has to be considered as a true difference between the examined groups.

\section{Conclusions}

1. $I L-12 A$ and $I L-12 B$ polymorphic variants are associated in Caucasian HD patients with the anti-HBs phenotype.

2. The GA rs568408 IL-12A variant seems to be predictive for the development of protective immunization in response to hepatitis $\mathrm{B}$ vaccination in HD patients.

3. The AC rs3212227 IL- $12 B$ polymorphism is a predictor of favorable outcome after HBV infection in HD patients. HD patients that do not develop anti-HBs after $\mathrm{HBV}$ infection (HBsAg carriers or individuals with isolated anti-HBc serum profile) more frequently bear the $\mathrm{CC}$ rs3212227 IL-12B (12.7\% vs $2.2 \%)$ 
polymorphic variant than patients with $\mathrm{HBV}$-induced anti-HBs development.

Acknowledgments We would like to express our gratitude to physicians of the dialysis centers for their help in collecting the participants' data and consent during the study period. We would also like to thank Dr. Margarita Lianeri for her assistance.

Open Access This article is distributed under the terms of the Creative Commons Attribution License which permits any use, distribution, and reproduction in any medium, provided the original author(s) and the source are credited.

\section{References}

1. Morbidity and Mortality Weekly Report (2001) Recommendations for preventing transmission of infections among chronic hemodialysis patients. US Department of Health and Human Services. Centers Dis Control Prev 50:RR-5

2. Nahar K, Jahan M, Nessa A, Tabassum S (2011) Antibody responses after hepatitis $\mathrm{B}$ vaccination among maintenance haemodialysis patients. Bangladesh Med Res Counc Bull 37:88-91

3. Idrees MK, Batool S, Ahmed E (2011) Hepatitis B virus among maintainence haemodialysis patients: a report from Karachi, Pakistan. J Pak Med Assoc 61:1210-1214

4. Ferreira RC, Teles SA, Dias MA, Tavares VR, Silva SA, Gomes SA et al (2006) Hepatitis B virus infection profile in hemodialysis patients in Central Brazil: prevalence, risk factors, and genotypes. Mem Inst Oswaldo Cruz 101:689-692. doi:10.1590/S007402762006000600019

5. Cabrerizo M, Bartolomé J, De Sequera P, Caramelo C, Carreńo V (1997) Hepatitis B virus DNA in serum and blood cells of hepatitis B surface antigen-negative hemodialysis patients and staff. J Am Soc Nephrol 8:1443-1447. doi:1046-6673/0809-1443\$03.00/0

6. Hassan MM, Li D, El-Deeb AS, Wolff RA, Bondy ML, Davila M et al (2008) Association between hepatitis B virus and pancreatic cancer. J Clin Oncol 26:4557-4562. doi:10.1200/JCO.2008.17. 3526

7. Adachi S, Shibuya A, Miura Y, Takeuchi A, Nakazawa T, Saigenji K (2008) Impact of occult hepatitis B virus infection and prior hepatitis B virus infection on development of hepatocellular carcinoma in patients with liver cirrhosis due to hepatitis $\mathrm{C}$ virus. Scand J Gastroenterol 43:849-856

8. Kim MJ, Kwon OS, Chung NS, Lee SY, Jung HS, Park DK et al (2008) The significance of anti-HBc and occult hepatitis B virus infection in the occurrence of hepatocellular carcinoma in patients with $\mathrm{HBsAg}$ and anti-HCV negative alcoholic cirrhosis [article in Korean]. Korean J Hepatol 14:67-76. doi:10.3350/ kjhep.2008.14.1.67

9. Cendoroglo Neto M, Draibe SA, Silva AE, Ferraz ML, Granato C, Pereira CA et al (1995) Incidence of and risk factors for hepatitis $\mathrm{B}$ virus and hepatitis $\mathrm{C}$ virus infection among haemodialysis and CAPD patients: evidence for environmental transmission. Nephrol Dial Transplant 10:240-246 not applicable

10. Grzegorzewska AE, Kaczmarek-Leki V, Młot-Michalska M, Niepolski L (2011) Seroconversion rate to positivity for antibodies against core antigen of hepatitis $\mathrm{B}$ virus and duration of renal replacement therapy. Nephrol Dial Transplant 26:970-976. doi:10.1093/ndt/gfq499

11. Grzegorzewska AE, Kurzawska-Firlej D, Ratajewski W, Frankiewicz D, Niepolski L, Kaczmarek A (2010) Antibodies to core antigen of hepatitis B virus in patients on renal replacement therapy: association with demographic, clinical and laboratory data. Nephron Clin Pract 114:c194-c203. doi:10.1159/00026 2302

12. Cooksley H, Chokshi S, Maayan Y, Wedemeyer H, Andreone P, Gilson R et al (2008) Hepatitis B virus e antigen loss during adefovir dipivoxil therapy is associated with enhanced virusspecific CD4+ T-cell reactivity. Antimicrob Agents Chemother 52:312-320. doi:10.1128/AAC.00467-07

13. Wu JF, Wu TC, Chen CH, Ni YH, Chen HL, Hsu HY et al (2010) Serum levels of interleukin-10 and interleukin-12 predict early, spontaneous hepatitis B virus e antigen seroconversion. Gastroenterology 138:165-172. doi:10.1053/j.gastro.2009.09.018

14. Rossol S, Marinos G, Carucci P, Singer MV, Roger W, Naoumov NV (1997) Interleukin-12 induction of Th1 cytokines is important for viral clearance in chronic hepatitis B. J Clin Invest 99:3025-3033. doi:10.1172/JCI119498

15. Chow YH, Chiang BL, Lee YL, Chi WK, Lin WC, Chen YT et al (1998) Development of Th1 and Th2 populations and the nature of immune responses to hepatitis B virus DNA vaccines can be modulated by codelivery of various cytokine genes. J Immunol 160:1320-1329 0022-1767/98/\$02.00

16. Schirmbeck R, Reimann J (2001) Modulation of gene-gun-mediated Th2 immunity to hepatitis B surface antigen by bacterial CpG motifs or IL-12. Intervirology 44:115-123

17. Kalechman Y, Gafter U, Sobelman D, Sredni B (1990) The effect of a single whole-blood transfusion on cytokine secretion. J Clin Immunol 10:99-105

18. Shaashua L, Sominsky L, Levi B, Sorski L, Reznick M, Page GG et al (2012) In vivo suppression of plasma IL-12 levels by acute and chronic stress paradigms: potential mediating mechanisms and sex differences. Brain Behav Immun 26:996-1005. doi:10. 1016/j.bbi.2012.05.012

19. Kuvibidila S, Warrier RP (2004) Differential effects of iron deficiency and underfeeding on serum levels of interleukin-10, interleukin-12p40, and interferon-gamma in mice. Cytokine 26:73-81

20. Grzybowska EA, Wilczynska A, Siedlecki JA (2001) Regulatory functions of $3^{\prime}$ UTRs. Biochem Biophys Res Commun 288:291-295. doi:10.1006/bbrc.2001.5738

21. Chen X, Han S, Wang S, Zhou X, Zhang M, Dong J et al (2009) Interactions of IL-12A and IL-12B polymorphisms on the risk of cervical cancer in Chinese women. Clin Cancer Res 15:400-405. doi:10.1158/1078-0432.CCR-08-1829

22. Zwiers A, Seegers D, Heijmans R, Koch A, Hampe J, Nikolaus S et al (2004) Definition of polymorphisms and haplotypes in the interleukin-12B gene: association with IL-12 production but not with Crohn's disease. Genes Immun 5:675-677. doi:10.1038/sj. gene.6364131

23. Seegers D, Zwiers A, Strober W, Peña AS, Bouma G (2002) A TaqI polymorphism in the $3^{\prime}$ UTR of the IL-12 p40 gene correlates with increased IL-12 secretion. Genes Immun 3:419-423. doi:10.1038/sj.gene.6363919

24. Park JS, Cheong JY, Kang JK, Cho JH, Yu S, Shin HD et al (2007) Association of interleukin-12 gene polymorphism with persistence of hepatitis $\mathrm{B}$ virus infection and hepatocellular carcinoma [article in Korean]. Korean J Gastroenterol 50: 313-318

25. Wang C, Tang J, Song W, Lobashevsky E, Wilson CM, Kaslow RA (2004) HLA and cytokine gene polymorphisms are independently associated with responses to hepatitis B vaccination. Hepatology 39:978-988. doi:10.1002/hep.20142

26. Grzegorzewska AE, Wobszal P, Jagodziński PP (2012) Interleukin-18 promoter polymorphism and development of antibodies to surface antigen of hepatitis B virus in hemodialysis patients. Kidney Blood Press Res 35:1-8. doi:10.1159/0003 29932 
27. Grzegorzewska AE, Wobszal PM, Mostowska A, Jagodziński PP (2012) Antibodies to hepatitis B virus surface antigen and interleukin 12 and interleukin 18 gene polymorphisms in hemodialysis patients. BMC Nephrol. doi:10.1186/1471-2369-1375

28. Milich DR, McLachlan A, Chisari FV, Kent SB, Thorton GB (1986) Immune response to the pre-S(1) region of the hepatitis B surface antigen (HBsAg): a pre-S(1)-specific $\mathrm{T}$ cell response can bypass nonresponsiveness to the pre-S(2) and $\mathrm{S}$ regions of HBsAg. J Immunol 137:315-322

29. Yap I, Guan R, Chan SH (1992) Recombinant DNA hepatitis B vaccine containing Pre-S components of the HBV coat protein-a preliminary study on immunogenicity. Vaccine 10:439-442

30. European Best Practice Guidelines (2002) Prevention and management of HBV, HCV and HIV in HD patients. Nephrol Dial Transplant 17(suppl.7):78-87. doi:10.1093/ndt/17.suppl_7.73

31. Załączniki do rozporządzenia Ministra Zdrowia z dnia 18 kwietnia $2005 \mathrm{r}$.

32. Hahn LW, Ritchie MD, Moore JH (2003) Multifactor dimensionality reduction software for detecting gene-gene and geneenvironment interactions. Bioinformatics 19:376-382

33. Chen J, Liang Z, Lu F, Fang X, Liu S, Zeng Y et al (2011) Tolllike receptors and cytokines/cytokine receptors polymorphisms associate with non-response to hepatitis B vaccine. Vaccine 29:706-711. doi:10.1016/j.vaccine.2010.11.023

34. Yucesoy B, Sleijffers A, Kashon M, Garssen J, de Gruijl FR, Boland GJ et al (2002) IL-1 $\beta$ gene polymorphisms influence hepatitis B vaccination. Vaccine 20:3193-3196

35. Höhler T, Reuss E, Freitag CM, Schneider PM (2005) A functional polymorphism in the IL-10 promoter influences the response after vaccination with $\mathrm{HBsAg}$ and hepatitis A. Hepatology 42:72-76

36. Sleijffers A, Yucesoy B, Kashon M, Garssen J, De Gruijl FR, Boland GJ et al (2003) Cytokine polymorphisms play a role in susceptibility to ultraviolet B-induced modulation of immune responses after hepatitis B vaccination. J Immunol 170:3423-3428. doi:0022-1767/03/\$02.00

37. Cheong JY, Cho SW, Oh B, Kimm K, Lee KM, Shin SJ et al (2010) Association of interleukin-18 gene polymorphisms with hepatitis B virus clearance. Dig Dis Sci 55:1113-1119. doi:10. 1007/s10620-009-0819-Z

38. Li W, Jiang Y, Jin Q, Shi X, Jin J, Gao Y et al (2011) Expression and gene polymorphisms of interleukin $28 \mathrm{~B}$ and hepatitis $\mathrm{B}$ virus infection in a Chinese Han population. Liver Int 31:1118-1126. doi:10.1111/j.1478-3231.2011.02507

39. Xia Q, Zhou L, Liu D, Chen Z, Chen F (2011) Relationship between TNF- <alpha $>$ gene promoter polymorphisms and outcomes of hepatitis B virus infections: a meta-analysis. PLoS One 6:e19606. doi:10.1371/journal.pone.0019606

40. Zhang TC, Pan FM, Zhang LZ, Gao YF, Zhang ZH, Gao J et al (2011) A meta-analysis of the relation of polymorphism at sites 1082 and -592 of the IL-10 gene promoter with susceptibility and clearance to persistent hepatitis B virus infection in the Chinese population. Infection 39:21-37

41. Shin HD, Park BL, Cheong HS, Yoon JH, Kim YJ, Lee HS (2007) SPP1 polymorphisms associated with HBV clearance and HCC occurrence. Int J Epidemiol 36:1001-1008. doi:10.1093/ije/ dym093

42. Li Y, Shi Y, Chen J, Cai B, Ying B, Wang L (2012) Association of polymorphisms in interleukin-18 and interleukin-28B with hepatitis B recurrence after liver transplantation in Chinese Han population. Int J Immunogenet 39:346-352. doi:10.1111/j.1744313X.2012.01097

43. Chedid MG, Deulofeut H, Yunis DE, Lara-Marquez ML, Salazar M, Deulofeut R et al (1997) Defect in Th1-like cells of nonresponders to hepatitis B vaccine. Hum Immunol 58:42-51
44. Kardar GA, Jeddi-Tehrani M, Shokri F (2002) Diminished Th1 and Th2 cytokine production in healthy adult nonresponders to recombinant hepatitis B vaccine. Scand J Immunol 55:311-314

45. Vingerhoets J, Vanham G, Kestens L, Penne G, Leroux-Roels G, Gigase P (1994) Deficient T-cell responses in non-responders to hepatitis B vaccination: absence of TH1 cytokine production. Immunol Lett 39:163-168

46. Livingston BD, Alexander J, Crimi C, Oseroff C, Celis E, Daly K et al (1999) Altered helper T lymphocyte function associated with chronic hepatitis B virus infection and its role in response to therapeutic vaccination in humans. J Immunol 162:3088-3095. doi:0022-1767/99/\$02.00

47. Ishizuka T, Nitta K, Yokoyama T, Hayashi T, Futatsuyama K, Kimata N et al (2002) Increased serum levels of interleukin-12 may be associated with Th1 differentiation in hemodialysis patients. Nephron 90:503-504. doi:0028-2766/02/0904-0503\$18.50/0

48. Lonnemann G, Novick D, Rubinstein M, Dinarello CA (2003) Interleukin-18, interleukin-18 binding protein and impaired production of interferon-gamma in chronic renal failure. Clin Nephrol 60:327-334

49. Nakagawa S (2004) A farewell to Bonferroni: the problems of low statistical power and publication bias. Behav Ecol 15:1044-1045. doi:10.1093/beheco/arh107

50. Fabrizi F, Di Filippo S, Marcelli D, Guarnori I, Raffaele L, Crepaldi M et al (1996) Recombinant hepatitis B vaccine use in chronic hemodialysis patients. Long-term evaluation and costeffectiveness analysis. Nephron 72:536-543 0028-2766/96/0724$0536 \$ 10.00 / 0$

51. Shatat HZ, Kotkat AM, Farghaly AG (2000) Immune response to hepatitis B vaccine in haemodialysis patients. J Egypt Public Health Assoc 75:257-2575

52. Alavian SM, Tabatabaei SV (2010) The effect of diabetes mellitus on immunological response to hepatitis B virus vaccine in individuals with chronic kidney disease: a meta-analysis of current literature. Vaccine 28:3773-3777. doi:10.1016/j.vaccine. 2010.03.038

53. Douvin C, Simon D, Charles MA, Deforges L, Bierling P, Lehner V et al (1997) Hepatitis B vaccination in diabetic patients. Randomized trial comparing recombinant vaccines containing and not containing pre-S2 antigen. Diabetes Care 20:148-151

54. Cockcroft A, Soper P, Insall C, Kennard Y, Chapman S, Gooch C et al (1990) Antibody response after hepatitis B immunisation in a group of health care workers. Br J Ind Med 47:199-202

55. Navarro JF, Teruel JL, Mateos ML, Marcen R, Ortuno J (1996) Antibody level after hepatitis $\mathrm{B}$ vaccination in hemodialysis patients: influence of hepatitis C virus infection. Am J Nephrol 16:95-97

56. Hennig BJ, Fielding K, Broxholme J, Diatta M, Mendy M, Moore $\mathrm{C}$ et al (2008) Host genetic factors and vaccine-induced immunity to hepatitis B virus infection. PLoS One 3:e1898. doi:10.1371/ journal.pone.0001898

57. Du DW, Jia ZS, Li GY, Zhou YY (2003) HBV DNA vaccine with adjuvant cytokines induced specific immune responses against HBV infection. World J Gastroenterol 9:108-111

58. Zeuzem S, Carreño V (2001) Interleukin-12 in the treatment of chronic hepatitis B and C. Antiviral Res 52:181-188 PII: S01663542(01)00183-8

59. Lada O, Benhamou Y, Poynard T, Thibault V (2006) Coexistence of hepatitis B surface antigen (HBs Ag) and Anti-HBs antibodies in chronic hepatitis B virus carriers: influence of " $\mathrm{a}$ " determinant variants. J Virol March 80:2968-2975. doi:10.1128/JVI.80.6. 2968-2975.2006

60. Kohno H, Inoue T, Tsuda F, Okamoto H, Akahane Y (1996) Mutations in the envelope gene of hepatitis B virus variants cooccurring with antibody to surface antigen in sera from patients with chronic hepatitis B. J Gen Virol 77:1825-1831. doi:10.1099/ 0022-1317-77-8-1825 
61. Chan TM (2010) Hepatitis B and renal disease. Curr Hepat Rep 9:99-105. doi:10.1007/s11901-010-0042-6

62. Grzegorzewska AE, Kurzawska-Firlej D, Świderski A, de MezerDambek M, Frankiewicz D, Zaremba-Drobnik D et al (2008) Infections with hepatitis B virus in hemodialysis units of Wielkopolska. Przegl Epidemiol 62:29-37

63. Blumberg BS (1979) Sex differences in response to hepatitis B virus I History. Arthritis Rheum 22:1261-1266

64. London WT, Drew JS (2013) Sex differences in response to hepatitis $\mathrm{B}$ infection among patients receiving chronic dialysis treatment. HIV Clin Trials 14:17-20

65. Karaosmanoglu HK, Aydin OA, Nazlican O (2011) Isolated anti$\mathrm{HBc}$ among HIV-infected patients in Istanbul, Turkey. Vaccine 29:1721-1726. doi:10.1016/j.vaccine.2010.11.044
66. Sun HY, Lee HC, Liu CE, Yang CL, Su SC, Ko WC et al (2010) Factors associated with isolated anti-hepatitis B core antibody in HIV-positive patients: impact of compromised immunity. J Viral Hepat 17:578-587

67. Tsouchnikas I, Dounousi E, Xanthopoulou K, Papakonstantinou S, Thomoglou V, Tsakiris D (2007) Loss of hepatitis B immunity in hemodialysis patients acquired either naturally or after vaccination. Clin Nephrol 68:228-234

68. Barałkiewicz G, Juszczyk J, Grzegorzewska A, Czarnecki R (1996) The results of the vaccination against hepatitis B ('Engerix B') in dialysed uaemic patients [article in Polish]. Hepatologia Pol 3:11-14 